
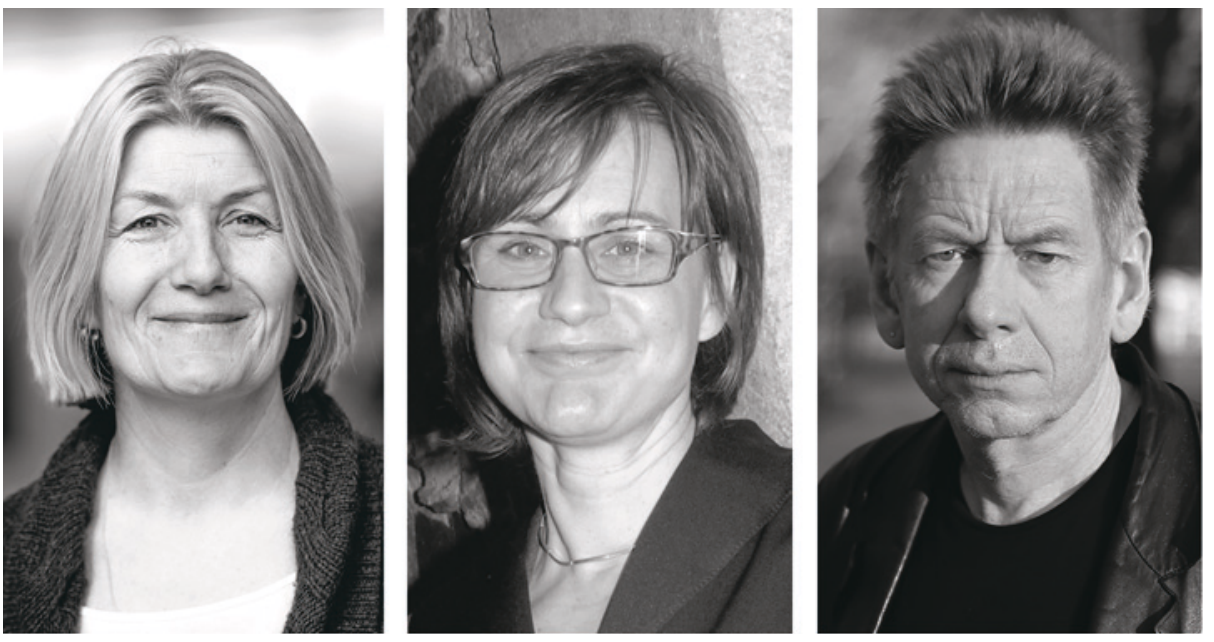

Fra venstre: Helle Schøyen (foto: Svein Lunde, Helse Stavanger) og Ute Kessler (foto: privat) er studiens førsteforfattere. Arne Vaaler er sisteforfatter (foto: Frode Nikolaisen, St. Olavs hospital)

\title{
Elektrokonvulsiv eller medikamentell behandling ved depresjon?
}

Elektrokonvulsiv terapi var mer effektiv enn farmakologisk behandling hos pasienter med tidligere behandlingsresistent bipolar depresjon.

De depressive fasene ved bipolar lidelse kan være langvarige og vanskelige å behandle. Elektrokonvulsiv terapi (ECT) blir av mange klinikere ansett som den mest effektive behandlingen, men dette er ikke dokumentert i randomiserte studier. En ny, norsk studie har undersøkt effekten av elektrokonvulsiv terapi sammenliknet med farmakologisk behandling hos slike pasienter (1).

Pasienter med behandlingsresistent bipolar depresjon $(n=73)$ ble randomisert til enten algoritmebasert farmakologisk behandling eller elektrokonvulsiv terapi tre ganger i uken. Etter seks uker var det størst reduksjon av depressive symptomer i gruppen som fikk elektrokonvulsiv terapi, med en forskjell i MADRS-skår på 6,6 poeng mellom de to gruppene. Responsraten var betydelig høyere i ECT-gruppen enn i medikamentgruppen (74\% vs. $35 \%$ ). Det var imidlertid ingen forskjell i remisjonsraten, som var lav i begge gruppene ( $35 \%$ vs. $30 \%)$.

- Dette er den første randomiserte studien der man sammenlikner effekten av kombinasjonsbehandling med flere psykofarmaka eller elektrokonvulsiv terapi, som er de to mest brukte behandlingsformene ved behandlingsresistent bipolar depresjon, sier Ute Kessler, som er en av artikkelens førsteforfattere og daglig leder for studien.

- Resultatene støtter bruken av elektrokonvulsiv terapi, spesielt når målet er rask bedring av depressive symptomer. Men studien viser også at bipolare depresjoner kan være vanskelig å behandle, noe som gjenspeiles i de lave remisjonsratene. Dette er viktig informasjon til klinikere som i samråd med pasientene skal ta avgjørelser omkring videre behandling, sier Kessler.

\section{Prisbelønnet multisenterstudie}

Studien er et samarbeidsprosjekt mellom sju psykiatriske akuttavdelinger i Norge. Forskningsnettverket BRAIN - Bipolar Research and Innovation Network - Norway er spredt over hele landet. Dette er en sammenslutning av klinikere og forskere med spesiell interesse for bipolare lidelser. Arne Vaaler, Gunnar Morken, Ulrik Malt og Ole Andreassen, som er sentrale personer i nettverket, har i betydelig grad bidratt til studien. Andre leger har bidratt ved å inkludere og behandle pasientene. Bjørn Auestad har gjort de statistiske analysene. Helle Schøyen og Ute Kessler har delt førsteforfatterskap for artikkelen. Begge har disputert på et tema knyttet til bipolare lidelser. Artikkelen ble kåret til beste forskningsartikkel innen akuttpsykiatri i 2014 av Nasjonalt forum for akuttpsykiatri, og ble av NEJM Journal Watch Psychiatry trukket frem som en av de ti viktigste publikasjonene i psykiatrifeltet internasjonalt.

\section{Lise Mørkved Helsingen \\ Tidsskriftet}

\section{Litteratur}

1. Schoeyen HK, Kessler U, Andreassen OA et al. Treatment-resistant bipolar depression: a randomized controlled trial of electroconvulsive therapy versus algorithm-based pharmacological treatment. Am J Psychiatry 2015: 172: 41-51.
Ordforklaringer

Bipolar depresjon: De depressive fasene ved bipolar lidelse kan være vanskelige å skille fra unipolare depresjoner, men krever en annen medikamentell behandling med mer vekt på stemningsstabiliserende medisiner fremfor antidepressiver.

Elektrokonvulsiv terapi (ECT): En medisinsk behandling der det sendes gjentatte korte, elektriske strømpulser gjennom hjernen som utløser et epileptisk anfall. Den nøyaktige virkningsmekanismen er fortsatt ukjent. Behandlingen brukes i hovedsak ved alvorlige behandlingsresistente depresjoner, men også ved andre livstruende psykiske lidelser. Behandlingen gis i narkose.

Montgomery-Åsberg depression rating scale (MADRS): Et tipunkts skåringsskjema for å vurdere alvorlighetsgraden av depressive symptomer.

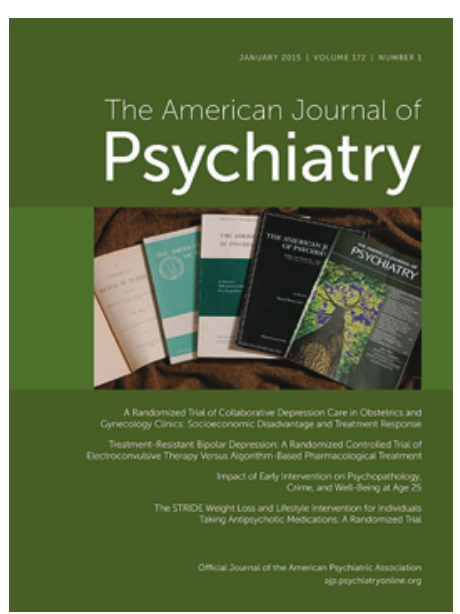

Artikkelen ble e-publisert i American Journal of Psychiatry 31. oktober 2014 